\title{
一方向凝固による $\mathrm{Al}-\mathrm{Si}$ 共晶繊維複合合金の組織についで
}

$$
\text { 三浦 維 四** 浜 中人 上** }
$$

Ishi Miura and Hitoshi Hamanaka : Microstructures of A1-Si Eutectic Fibrous Composites Produced by Unidirectional Solidification. Unidirectional solidification of eutectics offers a simple, inexpensive approach to the production of composite materials. The authors and coworkers have studied the production of fiber strengthening composite materials by various methods. In this paper, an attempt has been made to prepare Al-Si eutectic fibrous composites by means of unidirectional solidification. The main results are follows:

(1) In order to produce continuous structures of Al-Si eutectic alloys, it was found that solidification rate was less than $1.5 \mathrm{~mm} / \mathrm{hr}$ by using four or five nine aluminum and semi-conductor-grade silicon as materials.

(2) The cross section of silicon colonies showed four-fold symmetry and side branching, and individual silicon colonies extended over several millimeters in the growth direction. Wavy patterns of silicon phase were observed among straight silicon colonies in a cross section parallel to the growth direction.

(3) The growth mechanism of A1-Si eutectics seemed to differ from that of lamellar and rod-like structures, as silicon had a highly preferred growth direction. So the two phases did not exhibit any consistent orientation relationship.

(4) Impurities of materials have a considerable effect on the growth of silicon phases. So, if the factors which effect the growth of silicon phases is found, the shape of silicon colonies may be controlled, for example, by adding the third element to Al-Si eutectics.

(Received February 27, 1968)

\section{I. 緒 言}

共晶合金を一方向凝固することにより整列組織が得られ ることが最近知られるようになつたが，この方法を応用し て複合合金を作る方法が注目されている(1)(2)。これは凝固 の際に第二相を整列させることができるということから， 取扱いの困難な瀻維を複合材料汇組迟む手愢が省けるこ と，扰よび二相䦎の結合状態のよいものが得られるからで 方る。この方法によつてすでにいくつかのすぐれた性質を 持つ複合合金が得られている。蓑た一方向凝固法は凝固機

** 東京医科菡科大学笑用器材研究所 (Institute for Medical and Dental Engineering, Tokyo Medical and Dental University, Tokyo)

* 1967 年 10 月本会札猊大会に発表；金属組織と機栰 的性質の関係沉ついて(第 10 㪕)

(1) R.W. Hertzberg : Fiber Composite Materials, Am. Soc.Metals, Ohio, (1965), 77 .

(2) M. Salkind et al : Advanced Fibrous Reinforced Composites, SAMPE, 10 (1966), F 35.
構の解明に役立つことが知られている。この方法を応用し て，いろいるな共晶合金の組織制御の研究が行なわれると 同時に凝固機構の解明がなされつつある。Al-Si 共晶合金 は非連続共晶として分類されていたが(3)，Bell ら ${ }^{(4)}$ そつ て連絸組織が得られることが報告された。

著者らおよびその共同研究者はこれまで紻維強化合金作 製についていろいるな方法を陚みてきたが(5)〜(8)，共晶合 金の組織整列化に上る共晶䋊維複合合金の研究む進めてい $ろ^{(9)}$.

(3) G.A.Chakwick: Progress in Materials Science 12, 97.

(4) J.A.Bell and W.C.Winegard : J. Inst. Metals, 93 (1965), 318 .

(5) 三浅，太田，本間，佐々木：本誌，30(1966)，655.

(6) 三浦, 佐々木: 本誌, 30 (1966), 1099 .

(7) 三浦，本間：本赫，31 (1967)，475.

(8) 三浦, 本間: 本裉, $31(1967), 607$.

(9) 三浦，岩出，太田：本䙗，30(1966)，1005. 
この論文では一方向凝固法による $\mathrm{Al}-\mathrm{Si}$ 共晶合金の組織 を整列化するための条件を検討するとともに，凝固機構に ついてる考察を試みた.

\section{II. 実 験 方 法}

Fig.1 はここで用いた一方向凝固炉の主要部分の断面図

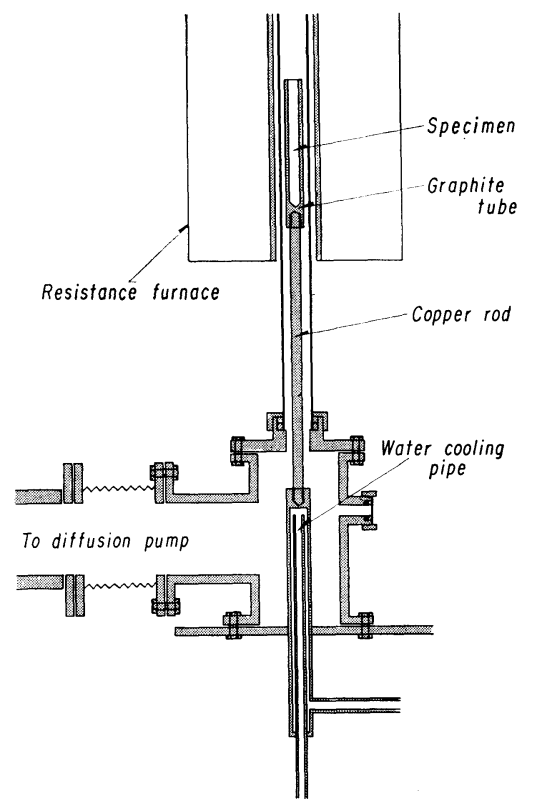

Fig.1 Schematic diagram of the apparatus

である。試料の溶解および一方向凝固は graphite tube の 中で行ならが，この graphite tube に十分温度公配をつけ， 熱の流れを強制的に一方向にするため，一端を水冷した銅 の丸棒の上に取り付けた。雾囲気は $10^{-5} \sim 10^{-6} \mathrm{mmHg}$ 程 度の真空とし, graphite tube の加熱は石英管の 外側から ニクロム抵抗炉によつて行なう。ニクロム抵抗炉の温度制 御は SCR 回路を用いて, 温度変化を $1 / 50^{\circ} \mathrm{C}$ 以下とした。 一方向凝固はこの炉を一定速度で移動することによつて行 なら。 graphite tube は原子炬用高純度黒鉛を内径 $10 \mathrm{~mm}$, 外 径 $14 \mathrm{~mm}$ に加工したものである.

用いた材料は主に $99.999 \% \mathrm{Al}(\mathrm{Cu} 1 \sim 2, \mathrm{Fe} 1 \sim 2, \mathrm{Si} 0.5$ $1, \mathrm{Mg}<0.5 \mathrm{ppm})$ と半導体用 $\mathrm{Si}$ (eleven nine の純度があ るといわれる)であるが，これらの他に比較のため $99.99 \%$ $\mathrm{Al}(\mathrm{Fe} 0.001 \%$, Si $0.001 \%, \mathrm{Cu} 0.001 \%$ 以下) 括よび $98.8 \%$ $\mathrm{Si}(\mathrm{Fe} 0.62 \%$, Ca 0.19\%, $\mathrm{Al} 0.04 \%$ ) む用いた.

これらの材料を $\mathrm{Al}-11.7 \mathrm{wt} \% \mathrm{Si}$ 共晶組成で溶解し, 700 ${ }^{\circ} \mathrm{C}$ で $20 \mathrm{hr}$ 保持した後に, 所定の温度勾配をつけ,一方向 凝固処理を行なつた。用いた凝固条件は，凝固速度 0.8 $15 \mathrm{~mm} / \mathrm{hr}$, 温度勾配 $8^{\circ} \sim 25^{\circ} \mathrm{C} / \mathrm{cm}$ である。このよ 3 にし て長さ $8 \sim 9 \mathrm{~cm}$ の試料を作り, $1 \mathrm{~cm}$ 間隔で切断し成長方 向に平行な断面拈よび直角断面の組織を観察した。 また $\mathrm{A} 1$ matrix の結晶方位を調べるためエッチピット法により Al の $\{100\}$ 面の観察を行なつた.

\section{III. 結 果}

凝固速度約 $1.5 \mathrm{~mm} / \mathrm{hr}$ 以下では Al matrix 中に $\mathrm{Si}$ colony の整列した組織を得ることができた，Phっむo.1はそ の代表的な組織である。凝固方向に平行な断面では $\mathrm{Si}$ 相 は平行に整列し，それぞれの Si colo.ny は3〜 $6 \mathrm{~mm}$ の長 さにも達した。直角断面では, Si colony の断面形状はれ 形となり, $\mathrm{Si}$ 相の板状部分での厚みは $2 \sim 3 \mu$ であり, 板 状の間の距離は $20 \sim 30 \mu$ である。しかし同一試料の他の 部分には, Photo.2 に見られるよ5な変つた組織が観察さ れまた陚料の先端部分にはPho:0.3 の上5な組織が見 られる。

凝固速度が $1.5 \mathrm{~mm} / \mathrm{hr}$ 以上になると整列度は悪くなる。 Photo. 4 は温度勾配 $15^{\circ} \mathrm{C} / \mathrm{cm}$ で凝固速度を変化させた場 合の組織の変化を示す.凝固速度の増加に伴ないSi colony 間に別の $\mathrm{Si}$ 相が晶出し整列度は悪くなる.凝固速度を 1.5 $\mathrm{mm} / \mathrm{hr}$ 以下にした場合は組織の変化はほとんど認められ ない, $0.8 \mathrm{~mm} / \mathrm{hr}$ まで調べたが Si colony 間の距離, 組織 の差は認められなかつた。

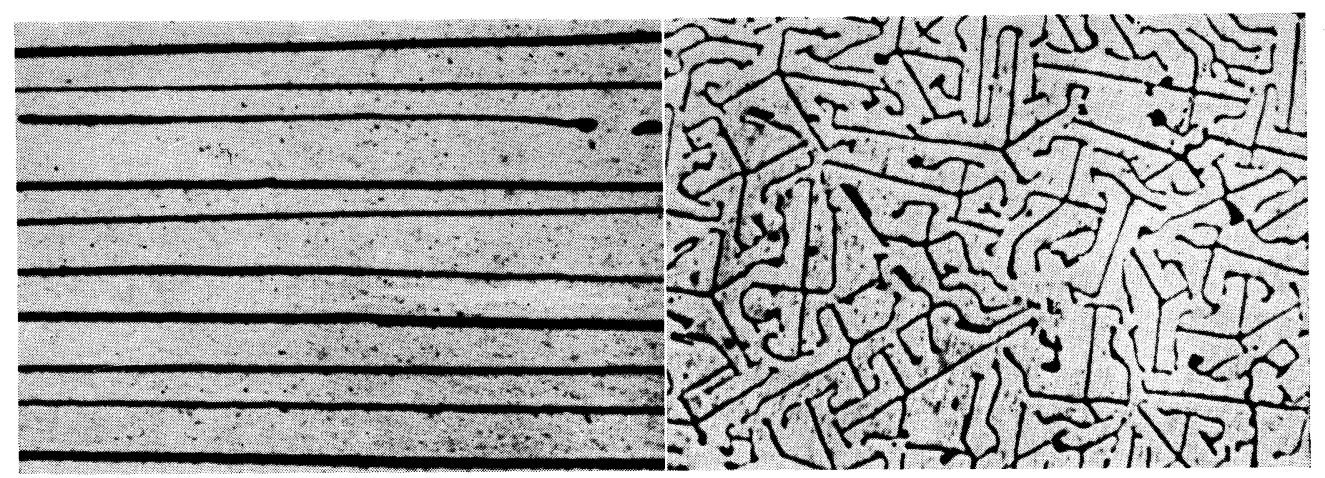

(a)

(b)

Photo.1 Typical structures of Al-Si eutectic composites $\begin{array}{ll}\text { (a) longitudinal section }(\times 100 \times 2) & \text { (b) transverse section }(\times 50 \times 2)\end{array}$ Solidification rate: $1 \mathrm{~mm} / \mathrm{hr}$; Temperature gradient: $10^{\circ} \mathrm{C} / \mathrm{cm}$ Unetched, aluminum matrix-white, silicon-dark 
温度勾配の 影響については $8^{\circ} \sim 25^{\circ} \mathrm{C} / \mathrm{cm}$ の範囲にわた つて調べたが，ほとんど影響は認められなかつた。このよ

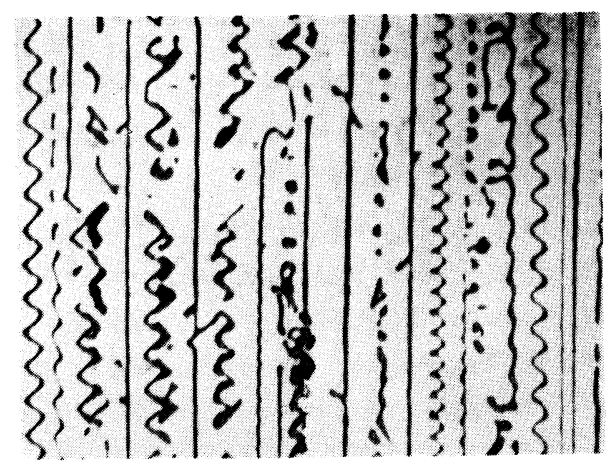

(a)
かなりの差があらわれ, Si colony の断面は枝分れする数 あ多くなり，不規則で角の部分が丸味を帯びてくる．さら に材料中の不純物が多くなると Photo.8 のような組織と なる。これは $99.99 \% \mathrm{Al}$ と $98.8 \% \mathrm{Si}$ を材料として用い た場合であるが，Si colony は連続でなくなり，断面の形 状もすつかり変つてくる.

$$
\text { IV. 考察 }
$$

$\mathrm{Al}$ - $\mathrm{Si}$ 共晶合金を一方向凝固することにより複合合金を 作り出すことができたが，緎維強化の目的が達せられるた めには連続した瀻維を整列させる必要があり，そのために は約 $1.5 \mathrm{~mm} / \mathrm{hr}$ 以下という非常に遅い凝固速度が必要で あつた。これはこれまで連続組織の得られている他の共晶
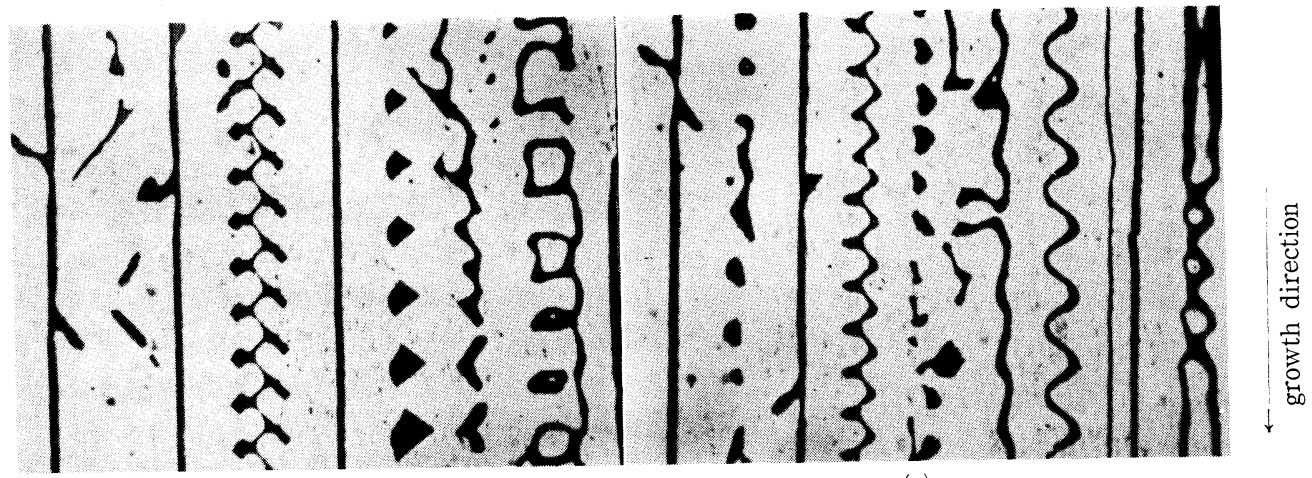

Photo.2 Wavy patterns of silicon phase in a longitudinal section of the same specimen as Photo.1. Unetched (a) $(\times 50 \times 2) ;(b),(c)(\times 100 \times 2)$

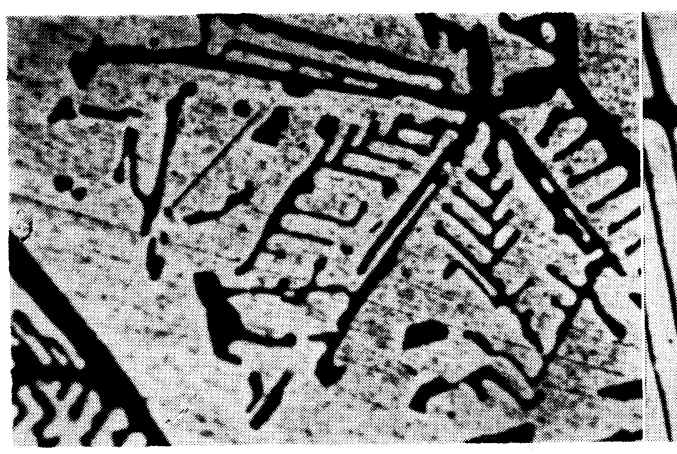

(a)

Photo.3 Structures in initial portions.

らな非常に遅い凝固速度では, 温度公配に対してあまり敏 感でないよ5に思われる。

Photo. 5 は $1 \mathrm{~mm} / \mathrm{hr}$ で疑固している途中で州を取り去 り，急速に凝固させたときの境界面付近の組織である． Si colony の間に針状の Si が晶出し，この部分の凝固が $\mathrm{Si}$ colony の成長よりる显れているここが考えられる。また Photo. 6 は $1 \mathrm{~mm} / \mathrm{hr}$ で凝固している途中から $30 \mathrm{~mm} / \mathrm{hr}$ に速度を変化させたときの組織の変化を示している。

Photo.7 は 99.999\% Alの代りに $99.99 \% \mathrm{Al}$ を用いた 場合の凝固方向に值角な断面の組織である。平行断面での 組織はあまり差がないが，直角断面に拉いてはこのように

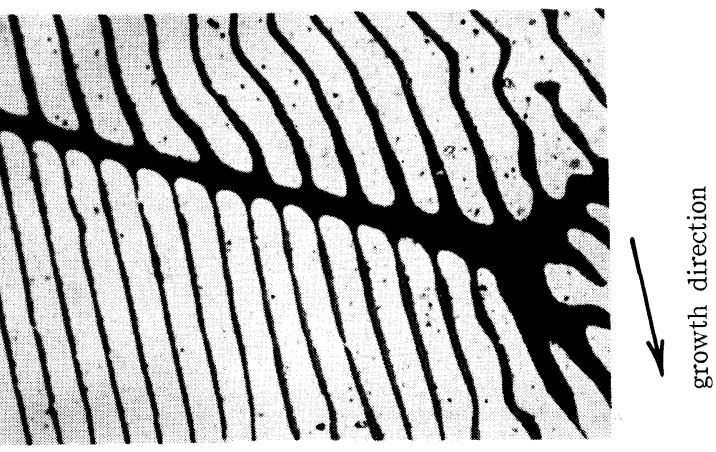

(b)

Unetched (a) $(\times 100 \times 2)$; (b) $(\times 100 \times 2)$

合金と比較するとかなり遅い。一般に共晶合金を整列化す ると, 第二相の体積比が 30 vol\% までは棒状組織，30〜50 vol\% では層状組織となることがいわれている，Al-Si 共 晶合金では Si 相の体積比は $13.3 \mathrm{vol} \%$ であるが，代形状 の断面の Si 相が整列した。 また連続組織となる場合, 直 線状にばかりでなく波形組織となる部分もあらわれた。

凝固速度, 温度勾配などの凝固条件の組織に扣よ注す影 響についてす他の合金系とはかなり異なつている，層状あ るいは棒状組織に招いては，第二相の間隔は凝固速度によ つて支配されることが報告されているが，A1-Si 共晶合金 ではこのような関係があてはまらないと思われる。たとえ 
ば,凝固速度については, 約 $1.5 \mathrm{~mm} / \mathrm{hr}$ 以上では Si colony の間に別の $\mathrm{Si}$ 相が晶出し，整列度が悪くなるだけであり，

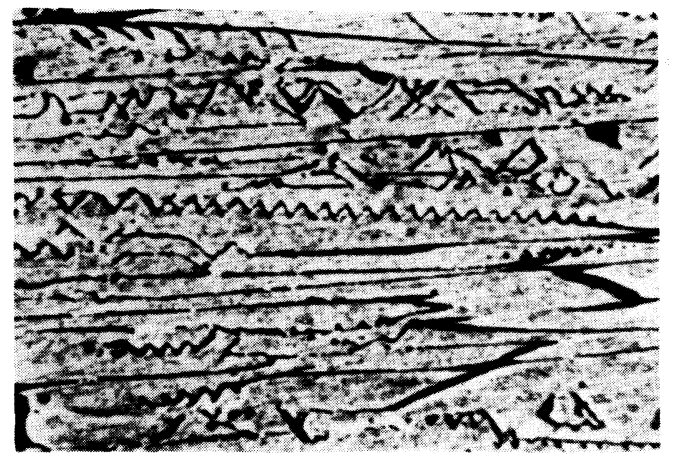

(a) solidification rate $4 \mathrm{~mm} / \mathrm{hr}(\times 50 \times 2)$

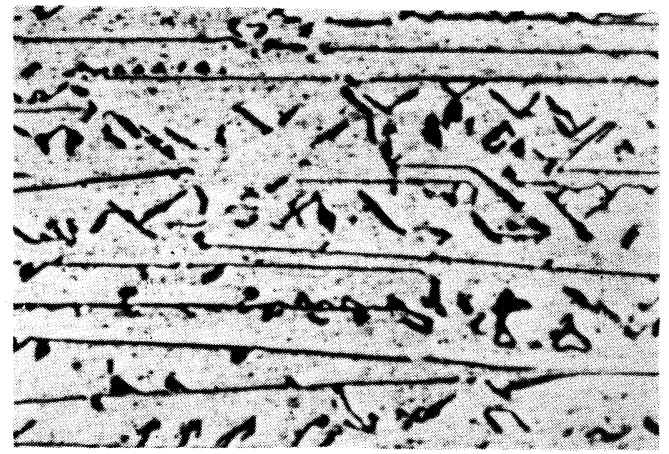

(b) solidification rate $6 \mathrm{~mm} / \mathrm{hr}(\times 100 \times 2)$

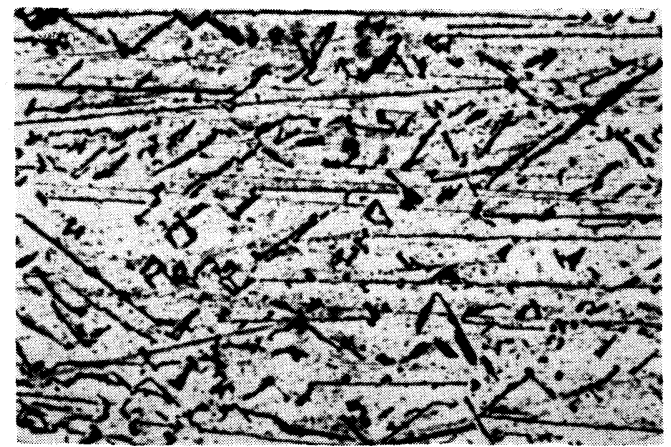

growth direction

(c) solidification rate $11 \mathrm{~mm} / \mathrm{hr}(\times 50 \times 2)$

Photo 4 Typical structures showing effest of growth rate in longitudinal sections

Si colony の間隔とは関係がなく,この速度以下についても ほとんど関係はないと思われる。また温度勾配についての 影響もここで用いた範囲内では，㴗とんど㤎められなかつ た。

二相間の結晶方位関係についてもほとんど関係づけられ ないと思われる。 Si 相は〈100>という非常に優先した成 長方位をもち匡とんどがこの方位に成長することが知られ ている.Al matrix との結晶方位関係を求めるためエッチ ピット法を用いて個々の Al matrix の結晶方位を観察し た.Photo.9 はそのらちの代表的なものを示したものであ るが,これらの間にはかなりの相違があり, Al matrix と Si 相との方位関倸を決定つけられなかつた。
このように Al-Si 共晶合金の整列凝固は，層状あるいは 棒状の整列組織とは相違点が多い。これは凝固のメカニズ

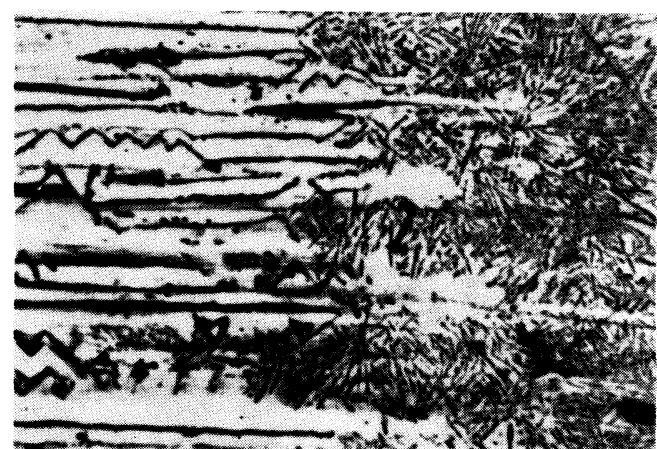

Composite Quenched

growth direction

Photo.5 Quenched interface in a longitudinal section. Unetched $(\times 50 \times 2)$

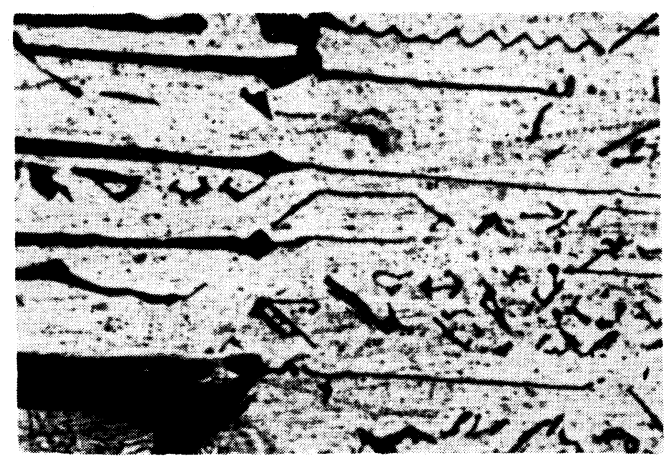

growth direction

Photo. 6 Change in a structure due $t$ ) the increase in solidification rate from $1 \mathrm{~mm} / \mathrm{hr}$ to $30 \mathrm{~mm} /$ hr $(\times 100 \times 2)$

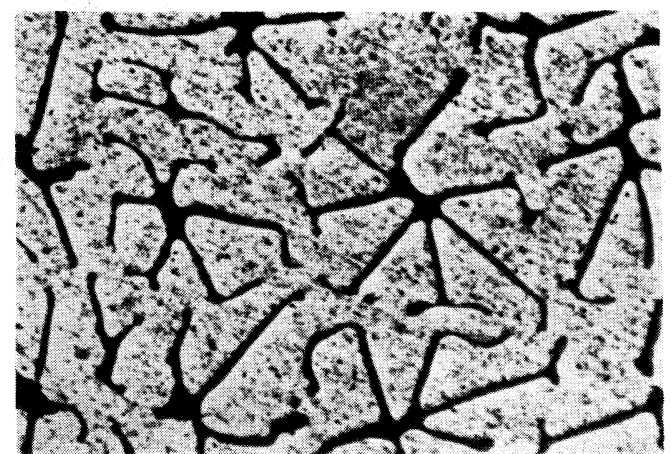

Photo.7 Transverse section in a specimen produced from $99.99 \% \mathrm{Al}$ and semi-conductor-grade $\mathrm{Si}$ solidification rate $1 \mathrm{~mm} / \mathrm{hr}$, temperature gradient $10^{\circ} \mathrm{C} / \mathrm{cm}$

Unetched $(\times 100 \times 2)$

ムがこれらのものとはかなり相違していることによるもの と思われる。

$\mathrm{Al}-\mathrm{Si}$ 其晶合金の一力问凝固している途中で急冷すると Photo.5のような組織が得られ，Si 相の方が $\mathrm{Al}$ 相よりも 先行していることが考えられる。また Photo.6は途中から 
$30 \mathrm{~mm} / \mathrm{hr}$ の凝国速度に変化したものであるが，このようがく100>方位へ突き出すが，凝固速度が遅いので，凝固 な速い凝固速度では Si 相は連続組織とはならないが、こ 万向ばかりでなく他のく100〉family direction へも成長

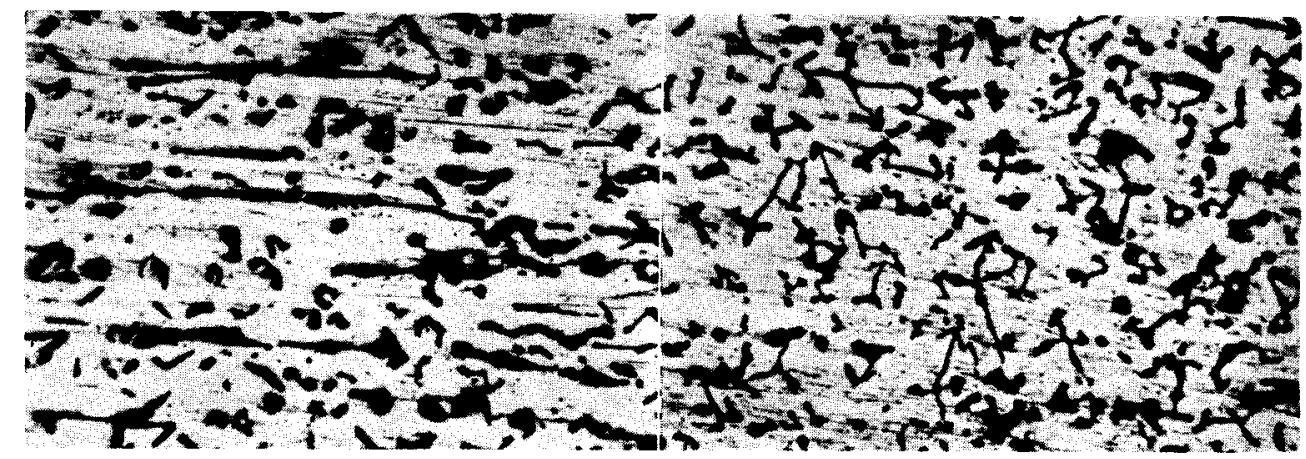

(a) growth direction

(b)

Photo. 8 Structures in a specimen produced from $99.99 \% \mathrm{Al}$ and $98.8 \% \mathrm{Si}$

Solidification rate $1 \mathrm{~mm} / \mathrm{hr}$, Temperature gradient $10^{\circ} \mathrm{C} / \mathrm{cm}$

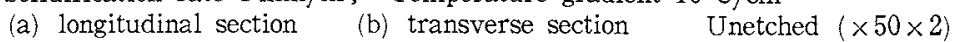

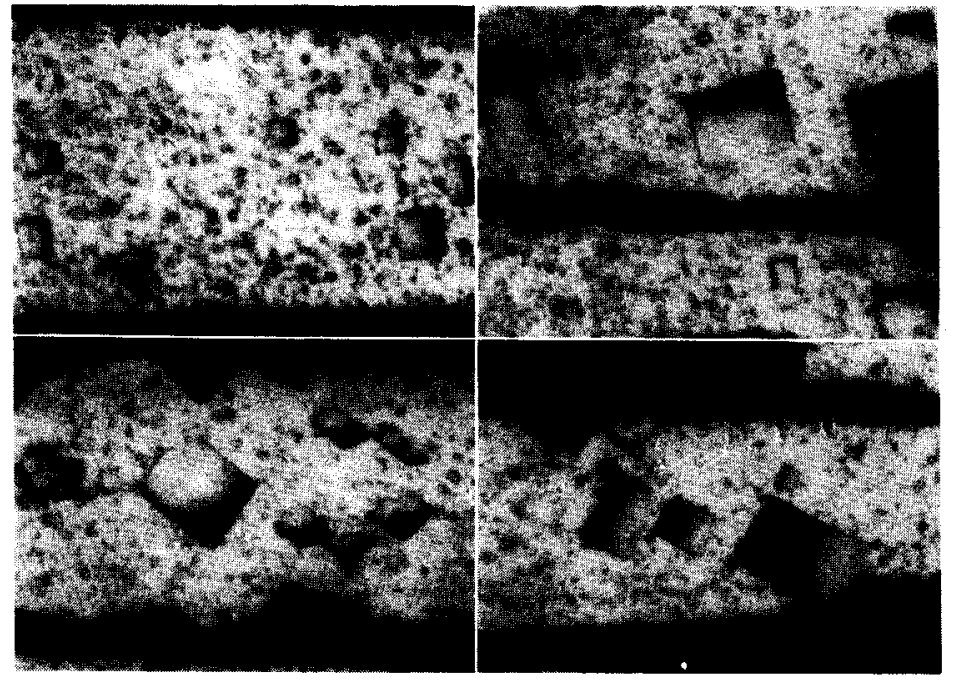

longitudinal section $(\times 400 \times 2)$

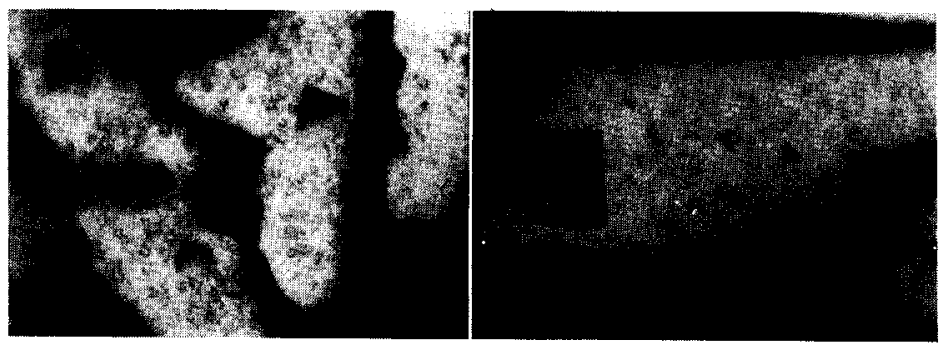

transverse section $(\times 400 \times 2)$

Photo.9 Etch pits on a aluminum matrix. (100) planes are developed
していく. Si colony の断面が遖角に枝分 れするのはこのためでるが，他にも双晶 に上ると思われる12〕’方向への枝分れ あかなり観察される。校分れした部分は古 る距催進をと隣りの Si colony との関係で 成层が比まるが，そこからまた横方向へ他 $の\langle 100\rangle$ 方向八成镸し, Si colony の断面 全体としては型形状になる. Photo.4の途 中で急冷した組織において，Si colony の 先端部が不揃いになつているのは Fig.2の ようなメカニズムによつて成長しているか らであると考学られ，固液界面他他共晶 合金のよ5に平らか，それに近いものでは ないことが考えられる、A1相はこのように Si 相を晶出しながら成長するのだが，A1一 Si 合金に特いて Si 相の晶出は比較的容易 であるとが知られて和り，少し凝固速度 が脨くなると簡単に别のところへ晶出して しま5。この上5に不規則方向へ向いた Si 相が晶出してしま5とAl matrix の成 長む妨げられ，Si 相の成長も連続になり にくくなる。Al一Si 洪晶合金において整列 組織が得にくいのは，Si 相が簡単に晶出 し，乙か子 Si 相の成長方向は<100>優 先才位であり，熱流によつて変化せず，こ の方向が㠜固方向と一致したものは長く伸
のように Si colonyに引絩いてかなり速く成長することが 麑祭された。

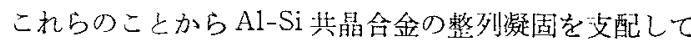
いる最む大きな要因は $\mathrm{Si}$ 相の成長であると考えられる。 A1-Si 其鼠合金に㕲いて Si 柏は<100>優先方位に成長す ることが知られているが，整列凝固のメカニズムとして

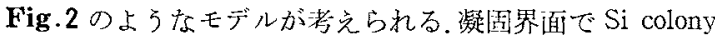

びるが，凝洞方向とある解度をるつるのは成長が止まり， 連続組織の成長を妨げてしまらことによると考えられる。 このため整列組織を得るには，Si 相の成長方位と凝固方向 の一致したるのだけを成長させるよ5に十分に㭙間をかけ て凝阁しなければならない。

凝固速度が非嫦に连い場合，Si 相の成舆方向之陚料の凝 固方向が一致しなくても連紿組織となり得る場合がある。 
これはPhoto.2 と見られるような波形の規則正しい繰返し 組織となることによつて試料の凝固方向へ成長することが

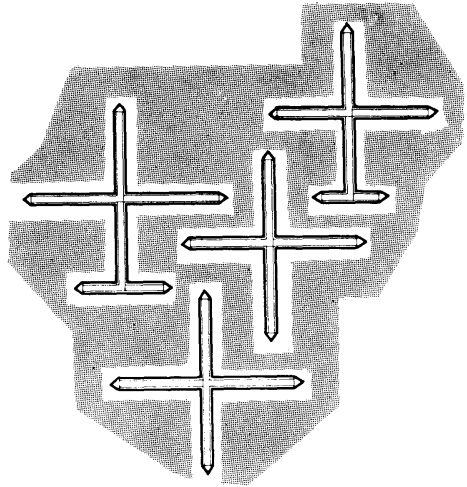

$\frac{\sqrt{3}}{\sqrt[3]{9}}$

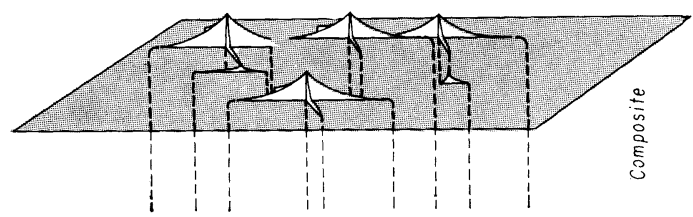

Fig.2 Proposed mechanism of growth of the A1-Si eutectic alloy

(a) plane figure

(b) schematic sketch

できるからである。波形模様の大部分は直角のジグザグで あるが，晶出した $\mathrm{Si}$ 相が凝固方向と $45^{\circ}$ かこれに近い場 合，る距離まで成長が進むとその部分の $\mathrm{Si}$ 原子はすで 飞隣りの Si 相へ拡散してしまい Si 原子濃度は低く，それ 以上成長できないが，反対方向へは Si 原子濃度は高く反 対方向への成長がはじまる，反対方向へ成長する場合 $<100>$ family direction へ成長し，またある距離進むと同 じようにひき返してくる。これを繰返すことによつて波形 模様となるが，波形模様の大部分が直角のジグザグとなる のはこのよ5に Si の $\langle 100>$ family direction への成長を 交互に繰返すためと思われる。角の部分に九味を帯びてい るのは表面エネルギーの関係で, 後に丸くなつたものと思 われる。しかし中には双晶によると思われる非常に変つた 波形模様もあるが数は少ない。このよ5な波形組織につい ての報告はあまりないようであるが，このような組織とな るのも $\mathrm{Si}$ が<100>といら非常に優先した方位を持つこ とによると思われる。このよ5に $\mathrm{Al}-\mathrm{Si}$ 共晶合金の凝固の メカニズムは他の共晶合金とは少し異なつているが，これ は第二相として晶出する $\mathrm{Si}$ が非金属に近い性質をるつと

\section{いうことによると思われる。}

$\mathrm{Al}-\mathrm{Si}$ 共晶合金の組織に招よぼするう一つの要因とし て，材料中の不純物の影響があげられる，材料として four nine $\mathrm{A} 1$ を用いた場合，凝固方向と直角な断面の形状はか なり異なつている。ささらに材料中の不純物の量が增加する と組織はすつかり変つてくる(Photo.8)。材料中に不純物 が入ると Si colony の断面形状が変るばかりでなく，波形 組織もあらわれなくなる。このように第三元素, あるいは その他が存在することによつて $\mathrm{Si}$ 相の成長は抑制される と思われるが，どの元素が，どのようなメカニズムによつ て Si の成長を妨げるのかは検討中である，第三元素を添 加することによつて Si colony の形状を適当に制御するこ とも可能であると考兄られる。

\section{V. 総 括}

一方向凝固法を用いて，Al matrix 中に Si colony の整 列した複合合金を作り出す研究を行なつたが，ここで得ら れた結果を総括するとつぎのようになる。

(1) Al-Si 共晶合金の整列組織を得るためには five nine $\mathrm{Al}$ あるいは four nine $\mathrm{A} 1$ と超高純度 $\mathrm{Si}$ を材料として用 いた場合 $1.5 \mathrm{~mm} / \mathrm{hr}$ 以下の凝固速度が 必要であつた。温 度勾配については調べた範囲内ではあまり影響が認められ なかつた。

(2) 得られた整列組織はて形状の断面をるつ Si colony が Al matrix 中に平行に整列したものであるが, 整列組 織の間にはめずらしい波形のジグザグ模様があらわれた.

(3) Al-Si 共晶合金の凝固機構は層状あるいは棒状組織 のそれとはかなり異なつていると思われる. また Al matrix と Si colony の間の結晶学的な方位関係は見出されなから た。これは第二相の $\mathrm{Si}$ が非金属の性質に近く，しかも $<100>$ とい非常に優先した成長方位をもつていること によるものと思われる。

(4) 材料中に不純物が存在すると Si colony の形状は大 きく影響を受ける。どの元素がどのように影響を拉よぼす かはわからないが，第三元素の添加によつて Si colony の 形状を制御することも可能であると考兄らる。

終りに，この研究を進めるにあたつて，有益な御助言を いただいた東京大学 椙山正孝教授に, 高純度 Si を提供下 さつた小松電子金属株式会社. 倉富龍郎社長，および赛験 に協力していただいた高橋和子君に厚く感謝の意を表した い. 